\title{
Nature's Eden? The Production and Effects of 'Pristine' Nature in the Galápagos Islands
}

\author{
Elizabeth Hennessy \\ Department of Geography and Center for Galápagos Studies, \\ University of North Carolina at Chapel Hill, USA \\ eah@email.unc.edu
}

and

Amy L. McCleary

Department of Geography, Center for Galápagos Studies and Carolina Population Center

University of North Carolina at Chapel Hill, USA

alnorman@email.unc.edu

\begin{abstract}
Best known for inspiring Charles Darwin's theory of evolution, the Galápagos Islands are often referred to as an "evolutionary Eden" and celebrated as one of the world's few remaining bastions of "pristine" nature. However, recent concerns of a crisis of overdevelopment prompted UNESCO to put the Galápagos on its list of World Heritage Sites "In Danger." In this paper, we interrogate the conception of pristine nature which undergirds the recent crisis discourse and argue that such understandings of nature are not in fact natural, but are social productions that reflect particular ways of understanding island space. We then explore the material and political effects of understandings of "pristine" nature by showing how they work to structure the tourism industry and investment in public infrastructure in ways that have created social inequalities as well as negative environmental impacts. We then briefly discuss measures taken so far to address the crisis situation, arguing that they would benefit from critical attention to the complexity of social-environmental relations in the Galápagos and a re-thinking of the nature of the islands.
\end{abstract}

Keywords: conservation; Darwin; environmental crisis; Galápagos; islands; nature; tourism

(C) 2011 Institute of Island Studies, University of Prince Edward Island, Canada.

\section{Introduction: The Crisis Moment}

The Galápagos Islands (Figure 1) have made news headlines around the world over the past four years: not for the unusual, pristine nature for which they are so well known, but because of what has been locally called a crisis. In 2007, the State of Ecuador declared the archipelago to be "at risk" and UNESCO inscribed it on its list of World Heritage Sites "In Danger" because increases in tourism, migration and the introduction of non-native species were seen as threatening the archipelago's prized biodiversity (Watkins \& Cruz, 2007). The paradoxical image of a "crisis in paradise" (Quiroga, 2009) has made for a popular news story - the idea of a crisis of out-of-control development in a place best known as a site of untouched nature asks readers to fundamentally rethink their understanding of the Galápagos. How can one place be home to both pristine nature (Figure 2) and rapidly growing society (Figure 3)? 
In this paper, we use this crisis moment as an opportunity to call for a re-imagination of the nature of the Galápagos. In discourse about the crisis, the international conservation community and the Ecuadorian state present the essence of the Galápagos - its unique, special nature - as threatened because of recent changes, particularly increases in tourism and population growth. Without action in these areas to reverse the current trajectory, the argument is, this previously "pristine" sanctuary of Darwinian nature will be lost. Yet, following much work in geography and environmental history, we argue that understandings of "pristine" nature in the Galápagos are not in fact natural, but are social productions that reflect particular ways of understanding island space and have important material and political consequences (Cronon, 1996; Sluyter, 1999; Hinchliffe, 2007). In the Galápagos, we argue that understandings of "pristine" nature work to frame the crisis discourse in such a way that ignores the fact that idealizations of the Galápagos as a space of previously untouched nature are not a representation of reality, but a particular way of thinking that has become deeply ingrained. We argue that critical examination of such idealizations is a necessary complement to existing analyses of ongoing crisis in the Galápagos, which have focused primarily on economic and political issues from a variety of perspectives (c.f., Ospina, 2006; Grenier, 2007; Watkins \& Cruz, 2007; González et al., 2008; Quiroga, 2009). We expand on existing ethnographic analyses of the Galápagos as a social and ideological construct (see especially Ospina, 2006; Quiroga, 2009) by examining the material and conceptual effects of particular understandings of the Galápagos as they relate to contemporary problems.

If understandings of pristine nature are not natural, then they must be explained. This is our task in the first half of the paper, in which we explore the production of understandings of "pristine," Darwinian nature in the Galápagos, focusing on a key moment in the mid- $20^{\text {th }}$ century when the Galápagos National Park was founded. Drawing on fieldwork we have conducted in the Galápagos, we then turn to explore the material and political effects of these commonsensical understandings of "pristine" nature by showing how they have shaped conservation management and have also worked to structure the tourism industry and investment in public infrastructure in ways that create social inequalities and negative environmental impacts. Over the course of the past four summers, we have conducted more than 125 interviews with a variety of stakeholders (including local residents, governmental and non-governmental agencies) in the Galápagos on issues ranging from understandings of this crisis moment to specific concerns about governance, development, landscape dynamics, water and health. In this paper, we draw generally from the information gathered in these interviews, our experiences in the islands, and other studies of the Galápagos. Our point, then, is not to explore or evaluate the causes or consequences of this crisis (which is important work to be done), but to interrogate the conception of nature which we argue undergirds the crisis discourse and its material effects. In the final section, we briefly discuss measures taken so far to address the crisis situation, arguing that in addition to political reform, economic management, and attempts to bring more stakeholders into decision making, critical attention to ways of thinking about nature is also necessary for a more suitable approach to conservation. 
Figure 1: The Galápagos Islands. The four inhabited islands (Isabela, Floreana, San Cristobal, and Santa Cruz) include rural and urban communities, as well as areas protected by the Galápagos National Park (GNP). The protected areas are sub-divided into three management zones, shown in green.

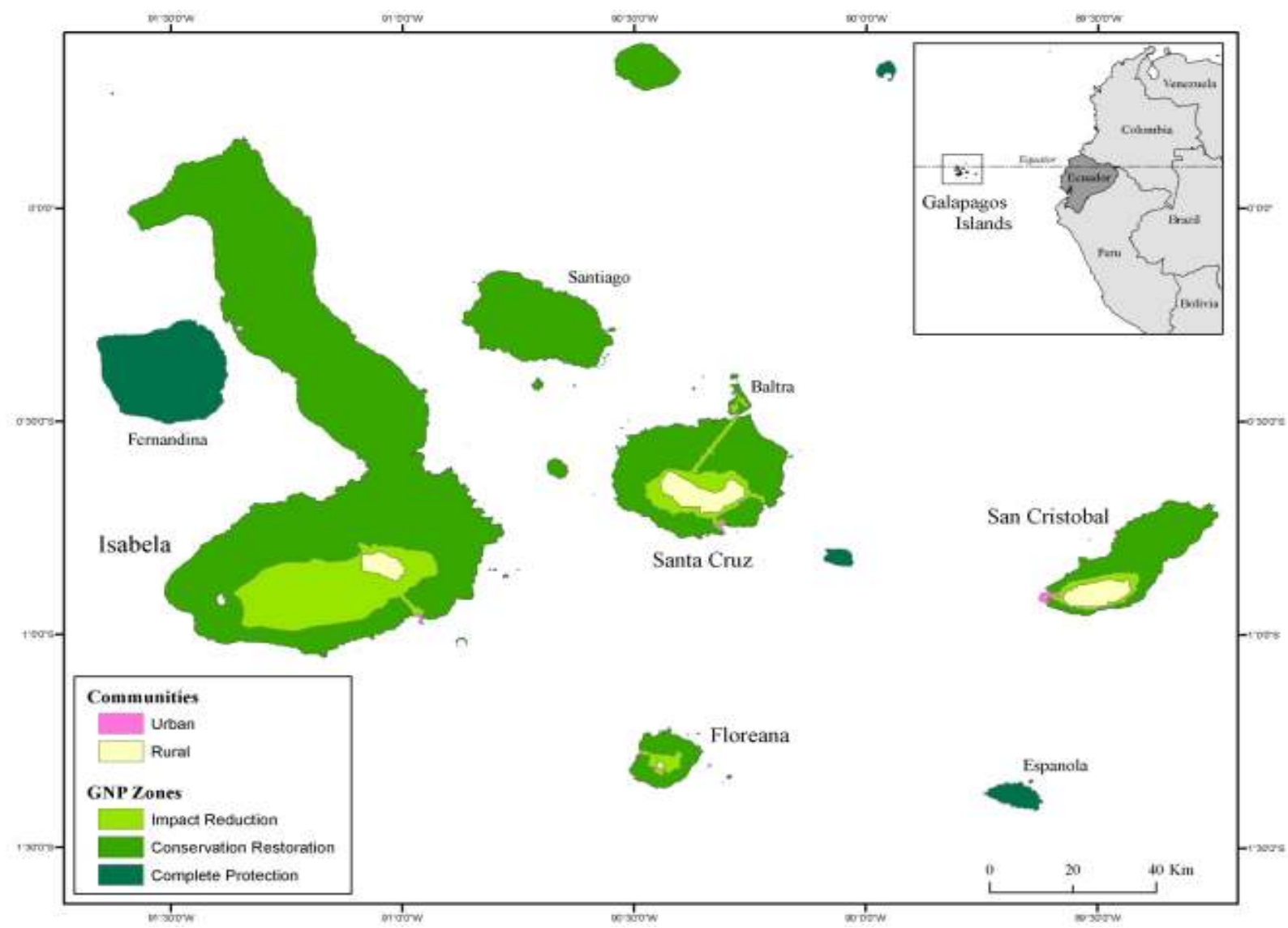

Sources: Galápagos National Park Service (main map); Environmental Systems Research Institute (ESRI), 2002 (inset map). Original map created by Amy McCleary.

\section{Nature's Paradise?}

The Galápagos Islands are best known for their endemic biodiversity-their unusual giant tortoises, flightless cormorants, and marine iguanas - and for inspiring Darwin's theory of evolution. As Darwin wrote in his Beagle journal, in the Galápagos, “...in both space and time, we seem to be brought somewhat near to that great fact - that mystery of mysteries - the first appearance of new beings on this earth" (Darwin, n.d. [1845]: 359). Today, conservation and tourism literature casts the islands as a "lost paradise" (Salwen, 1989) that somehow remains almost completely removed from modernity. This image is reinforced in nature documentaries, travel writing, and popular science discourse that present images of the islands' austere, volcanic landscapes and their unusual species; depict Darwin collecting on the islands' rocky shores; and describe how the archipelago's animals do not fear humans. In these accounts, the islands are not only shown as a people-less landscape (with the exception of Darwin), but the islands' unique, harsh nature is presented as self-evidently demonstrating 


\section{E. Hennessy \& A. L. McCleary}

evolutionary processes. The Galápagos seem to be a place in which scientists and tourists alike can return to a land before time where giant reptiles ruled the world and where seemingly prehistoric creatures are surprisingly un-impacted by human presence.

Yet, such views stand in stark contrast to recent descriptions of a crisis in the islands: in April 2007, Ecuadorian President Rafael Correa declared the islands to be in a state of risk and pledged to make their conservation a national priority; two months later, UNESCO added the Galápagos to the IUCN list of World Heritage Sites "In Danger." Both declarations cited concern about uncontrolled increases in tourist visits to the archipelago, growing illegal migration, and invasive species: since 1990, tourist visits have increased four-fold to more than 170,000 a year and in the past 10 years the local resident population has doubled to nearly 30,000 people as continental Ecuadorians immigrate to the islands in search of jobs in the booming industry (Watkins \& Cruz, 2007). While the Galápagos are estimated to retain 95\% of their "original" (i.e., pre-discovery) biodiversity (CDF \& WWF, 2002), scientists and conservationists have expressed concern that an influx of invasive species associated with human flows are the primary threat to endemic biodiversity (Watkins \& Cruz, 2007). What has locally been called a "crisis" situation has made for a popular news story around the world. In a special edition of "Dan Rather Reports" in 2008, the famous news anchor explained the situation in the Galápagos as such:

"These islands, which are millions of years old, are now threatened by a very modern danger: tourism and commercial development. An important battle is being waged between Nature and Man here in the Galápagos. Nature was in complete control of these islands for millions of years. Step on the Galápagos and you step back in time, before recorded history, before Man left his first footprint on the planet. But that human footprint is now threatening what took Nature eons to create" (Rather, 2008).

However, geographers and environmental historians have long critiqued the dichotomous opposition between Man and Nature referenced in Rather's account and have contested the idea of "pristine" nature even in remote places like the Galápagos (Denevan, 1992; Cronon, 1996; Sluyter, 1999; Raffles, 2002). As William Cronon argued in a seminal text, "wilderness is not quite what it seems": opposed to being an untouched sanctuary that has miraculously not been contaminated by civilization, he instead argues that "pristine wilderness" is a product of particular philosophies and practices of modern life and thus "could hardly be contaminated by the very stuff of which it is made" (1996: 69). Opposed to being a pure space outside of, and often under attack by, society, nature in this view is profoundly a social production. For geographer Stephen Hinchliffe, the "myth of independent nature" (2007: 33) is problematic because it belies both the dense biophysical interconnections between people and nature and the myriad ways in which natures are endowed with social meanings (Castree, 2001; Raffles, 2002; Latour, 2004). 
Figure 2: One of the most photographed vistas in the Galápagos shows Pinnacle Rock in the right foreground and now uninhabited Santiago Island in the background.

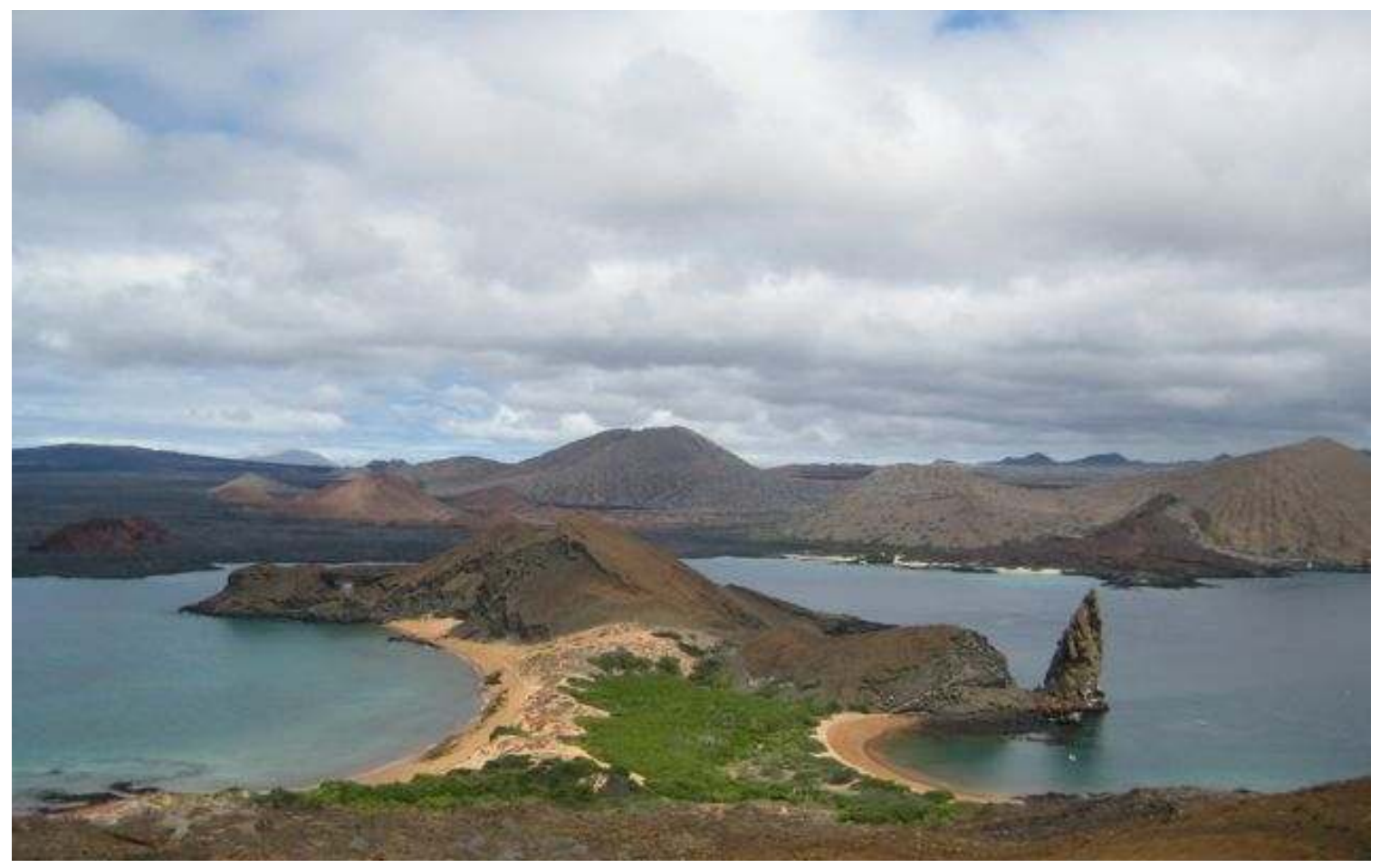

Photo by Elizabeth Hennessy

Tracing the changing valuations of the concept of wilderness from its original meaning as unproductive, unruly wasteland to untouched, ahistorical nature, Cronon demonstrates that understandings of nature change dramatically over time with changing philosophies and cultural values (also Worster, 1994; Soper, 1995). Like the concept of wilderness, ideas about the nature of the Galápagos have changed dramatically over the past 500 years. Before the Galápagos were famous as Darwin's "little world within itself" (Darwin, n.d. [1845]: 359), they were thought to be enchanted in a different sense - cursed and inhospitable because of their austere, volcanic terrain and almost total lack of fresh water (Larson, 2001). When he discovered them in 1535, Fray Tomas de Berlanga wrote that the islands looked like "God had showered stones" down upon them (quoted in Larson, 2001: 22). For centuries the islands were associated with a hell on earth because their landscape made them unfit for human life. Even Darwin wrote in his Beagle journal that "nothing could be less inviting than the first appearance" (Darwin, nd. [1845]: 354). These valuations began to change in the $19^{\text {th }}$ century, when the islands were seen as a significant source of natural resources and sought as a geopolitically strategic location. The islands were a popular stopover for whalers and buccaneers who used the giant tortoises as a source of fresh meat on their long voyages. Foreign interest in the islands prompted Ecuadorian colonization efforts in the $19^{\text {th }}$ and $20^{\text {th }}$ centuries, and between Darwin's visit in 1835 and the founding of the National Park in 1959, the islands were home to Europeans who responded to calls to create Swiss Family Robinsontype settlements on the islands, as well as penal colonies, sugar cane plantations, and eventually a US military base during World War II. It was not until the last half of the 20th 
century that the islands were widely celebrated for their unique biodiversity and their role in Darwin's research.

Attention to these social histories - which are rarely presented in nature documentaries or tourism propaganda - show that the Galápagos are not a pristine realm of untouched nature whose value is self-evident, but that even in such an apparently remote place, nature and culture are inseparable in two senses. First, the notion that Galápagos is a natural sanctuary devoid of people, as it is presented in nature documentaries, or that it was such before Darwin's visit, is false. The landscape has been shaped by people directly and indirectly since its discovery in 1535. Second, that the value attributed to the islands' nature has changed so dramatically - from being cursed because they were inhospitable to life to holding the secret of the very origins of life (Larson, 2001)_-demonstrates that the nature of nature cannot be taken to be self-evident, but must be understood in relation to particular historical and cultural contexts.

\section{Making an Evolutionary Eden}

If representations of the Galápagos as a site of pristine, isolated nature are not natural, then both their origin and how they came to be hegemonic must be explained. This involves tracing both conceptual and material transformations of Galápagos landscapes. Following geographer Andrew Sluyter's (1999) work on colonial Veracruz, falsifying the myth of pristine nature requires (a) demonstrating that ostensibly pristine landscapes were not in fact untouched or unproductive prior to colonization — or in the case of the Galápagos, prior to the conservation efforts with which the discourse became hegemonic; (b) tracing a conceptual transformation of the landscape from non-pristine to pristine; and (c) showing how these material and conceptual landscape transformations work to create a positive feedback loop that effectively conceals these changes. In what follows, we explore these themes in relation to discourses of pristine nature in the Galápagos.

Rethinking the history of Galápagos landscapes means recognizing that the commonsensical view of the Galápagos presented in nature documentaries and conservationist discourse is not a simple, apolitical reflection of the reality of the islands, but a particular vision of the islands produced through the very narratives that celebrate Darwin and isolation. In tracing the material and conceptual landscape transformations associated with these narratives - what Quiroga terms the "crafting of the Galápagos as a natural laboratory" (2009: 125)—we begin by discussing the previously mentioned social histories of the archipelago and their impacts on the islands' landscapes. We then turn to focus on the emergence of a 'pristine' narrative about the islands, which we argue became the dominant view of the archipelago-at least internationally - in the mid- $20^{\text {th }}$ century period surrounding the founding of the Galápagos National Park and the Charles Darwin Research Station. Finally, we turn to explore how this pristine discourse works through conservation landscape management and restoration plans to effectively complete a conceptual-material feedback loop that makes it difficult to see a history of the islands as anything other than pristine nature. We believe this is particularly important to understand because this feedback loop has also had the effect of polarizing political debate concerning the islands' future as a battle between Man and Nature or development and conservation. 


\section{A Non-pristine Material History}

Although the Galápagos have no indigenous human population, their landscapes have been shaped by human visitors for centuries. From the seventeenth to nineteenth centuries, pirates and whalers frequently stopped in the Galápagos to pick up giant tortoises, which made an excellent source of food. Not only was tortoise meat well-liked, but the animals could stay alive for lengthy periods - more than 100 days according to some reports - without food or water. Sailors would stack the animals in the hulls of ships before taking off for a voyage across the Pacific. In 1925, Townsend estimated that American whalers had taken as many as 100,000 tortoises from the Galápagos in the previous century. These early visitors also introduced goats and pigs to several islands, which reproduced abundantly and served as additional food sources for future voyages. These introduced species changed island ecosystems at such a scale that several nineteenth century visitors expressed concern. In 1869, one American collector reported many introduced animals on Floreana (Charles) Island ${ }^{1}$ as damaging for the islands' tortoises: "Pigs now roam in their haunts, destined to destroy their eggs and young whenever and wherever they may find them." A year later, a navy expedition found "tortoises to have almost disappeared from Charles Island," replaced by "several thousand head of wild cattle, besides pigs and goats" (both quoted in Larson, 2001: 94).

Yet poaching and introduction of foreign species were not the only human impacts on the islands. Since the early 1800s, the islands have been home to numerous small-scale settlements. The earliest known inhabitant was a marooned sailor named Patrick Watkins who lived on Floreana Island for several years in the early $19^{\text {th }}$ century. When Darwin visited the island in 1835, Watkins was gone, but a settlement of about 200 people existed - most of whom were Ecuadorian political prisoners under the direction of an English vice-governor (Larson, 2001). Indeed, it was Governor Lawson who famously mentioned to Darwin that he could tell which island a particular tortoise came from based on the shape of its carapace.

Lawson's colony was only one of several that have existed since the islands were first colonized. Over the past 200 years, people have lived on six of the archipelago's thirteen large islands (five are currently inhabited), under a broad range of circumstances. In the $1800 \mathrm{~s}$, the islands were primarily home to Ecuadorian political exiles and a state penal colony. During the $19^{\text {th }}$ and $20^{\text {th }}$ centuries, the state encouraged colonization of the islands to legitimate its sovereignty against foreign governments' attempts to buy the islands-for their guano reserves, to use as a coaling station, and later as a site from which to protect the Panama Canal. During the $20^{\text {th }}$ century, the state turned toward promoting colonization for economic development. These development schemes included a sugar cane plantation and mill (with a small railroad) on San Cristobal (Chatham) Island, salt mines on Santiago (James), a tortoise oil industry on Isabela (Albermarle), an international tuna industry, and attempts to collect orchilla to use as dye. During the first half of the $20^{\text {th }}$ century, the Ecuadorian government even advertised colonization opportunities in European newspapers to entice people to create a Swiss Family Robinson-type existence on the islands. During the 1930s, several small groups of Europeans responded to these calls, though their settlements were far from a Hollywood dream. Early Galápagos life was notoriously difficult because of the islands' remoteness, lack of fresh water, and rough terrain. Most people at the time lived on small agricultural

\footnotetext{
${ }^{1}$ The archipelago's islands have both English and Spanish names. We use Spanish names, as is common practice today. The historical English names are given in parentheses.
} 
settlements. But during the 1930s, the Galápagos were best known in U.S. and European newspapers for the sordid affairs of a European nudist colony and the murder mystery surrounding the self-proclaimed "Empress of Galápagos" and her male companions.

During World War II, the archipelago's location made it geopolitically significant — this time for the United States, which rented Baltra Island to use as an air force base from which to protect the Panama Canal. The Americans built an airport, a pier, 408 buildings, and 32 miles of asphalt-paved roads, the first in the archipelago, to support about 2,000 men stationed there (Harrison, 1947). When the base closed in 1946, it was taken over by the Ecuadorian military and the infrastructure facilitated state-led settlement programs.

By the 1960s, the islands were home to about 2,000 people. Most inhabitants subsisted on hunting feral animals and by growing fruits and vegetables, particularly in the humid highlands of the larger islands - Santa Cruz (Indefatigable), Isabela (Albermarle) and San Cristobal (Chatham) — where the largest populations exist today.

\section{A Conceptual Shift}

The landscapes of the Galápagos were thus far from "pristine" by the time the National Park was founded and even when Darwin visited. Feral livestock and increasing settlements were a principal concern for the scientists and conservationists who fought to establish a biological reserve in the archipelago. As Edward Larson recounts in his history of science on the islands, during the 1950s an international group of scientists came together to advocate some kind of permanent base on the islands from which to conduct research and to enforce protection measures. We argue that it was at this point that discourses of the Galápagos as a site of "pristine" nature gained international currency. Although scientists had worked to protect the islands for decades, ideas about their value as "pristine" nature did not become hegemonic until they were applied to conservation management in the mid- 20 th century.

In 1957, UNESCO, the United Nations Environmental, Scientific and Cultural Organization, sent two scientists, German ethnologist Irenäus Eibl-Eibesfeldt and American ornithologist Robert Bowman, on a reconnaissance mission to explore the establishment of a permanent scientific research station in the islands. In their reports, the men expressed concern about recent settlements, wild animals, and the near total environmental destruction caused by the military base on Baltra. Bowman's (1960) report discusses the historical and scientific importance of the archipelago as well as the principal threats to its wildlife: the tuna fishery, poaching by local residents, and foreign species including goats, pigs and dogs introduced by recent settlers as well as by early sailors. By 1959, the centennial of the publication of On the Origin of Species, the recently formed Charles Darwin Foundation (CDF) for the Galápagos Islands (working with UNESCO) was able to convince the Government of Ecuador to support a national park and biological research station in the islands. The aim of the CDF's Charles Darwin Research Station was to facilitate biological research in the islands as well as to provide technical expertise to the new national park concerning the protection of the archipelago's unusual flora and fauna. 
Figure 3: Galapagueño men play EcuaVolley in a park in central Puerto Ayora on Santa Cruz Island. A number of tourism businesses can be seen in the background. Such common street life scenes are rarely shown in tourism or nature-focused media about the islands.

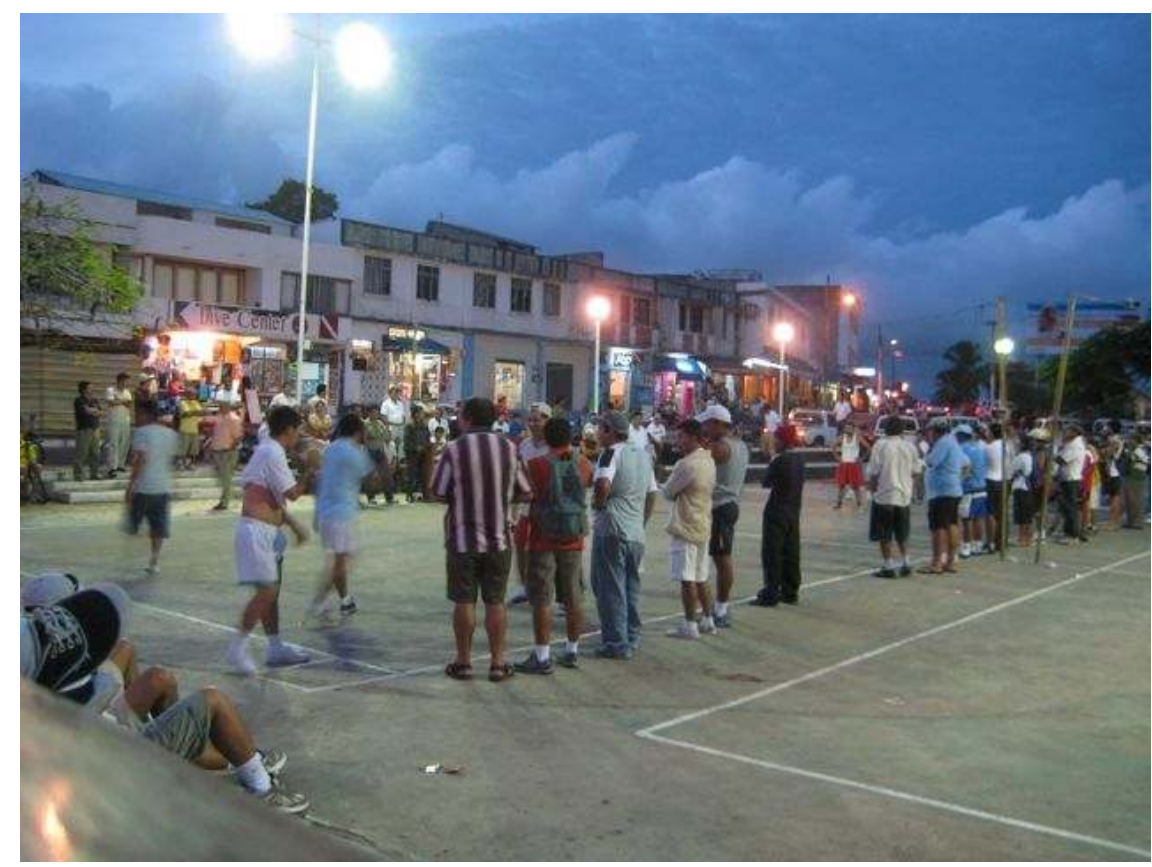

Photo by Elizabeth Hennessy.

For Bowman, Eibl-Eibesfeldt, and other scientists involved in the CDF, the growing human population on the islands and the state's desire to continue colonization in pursuit of economic growth were key motivations for conservation efforts. Conservation was justified by rhetoric focused on the islands' scientific value. The public face of these conservation efforts was Julian Huxley, the founding director of UNESCO and first president of the CDF, for whom the islands' scientific value was of personal interest. The great-grandson of "Darwin's bulldog" T.H. Huxley, Julian had a personal tie to these islands, which he considered the birthplace of Darwin's evolutionary thought. In 1959, he argued that:

"The Galápagos Archipelago is historically of great scientific importance, since it was its fauna and flora which more than anything else convinced Charles Darwin of the fact of evolution... It provides indeed one of Nature's most clear-cut experiments in evolution, and for this reason, and as a memorial to Darwin's great achievement, its flora and fauna should be studied, preserved and safeguarded" (Huxley, quoted in Larson, 2001: 12).

For Huxley, the national park commemorated the hallowed ground from which Darwin discovered the "origin of species," from which evolutionary theory was born. As he wrote near the centennial celebration of the publication of On the Origin of Species: 
"It was on the Galápagos...that Darwin took the first step out of the fairyland of creationism into the coherent and comprehensible world of modern biology; for it was here that he became fully convinced that species are not immutable - in other words, that evolution is a fact" (Huxley, 1966: 3).

Today, this rhetoric, which presents the Galápagos as an evolutionary Eden, the site of a scientific origin story, is repeated in numerous popular science books on the islands, nature documentaries, and tourism propaganda that pitch the Galápagos as "the islands that changed the world" (Stewart, 2007), a "geological and biological Eden" (Dawkins, 2007: 6), and "an almost perfect natural laboratory of evolution" (ibid.). We argue that the success of CDF's campaign and Huxley's rhetoric, and the fact that the view of the Galápagos they articulated has become so widespread, cannot be attributed solely to the influence of UNESCO nor to any natural reality of the islands. Rather, we argue that the narrative is so convincing because it combines deeply ingrained Western ideas about the importance of islands with a scientific understanding of island nature as isolated from human impact that is often taken at face-value because of widespread belief in the universal veracity of scientific knowledge. In the following section, we explore how imaginations of pristine nature in the Galápagos build on popular understandings of the nature of island Edens along with the scientific valuations of the islands' isolation.

\section{A Natural Laboratory}

Islands have long held a special place in modern thought, often associated with origin stories. Cast as remote and isolated, they are idealized as places of Edenic nature, primitive escapes from modernity, and small, controllable sites that lend themselves to utopic plans (Grove, 1996; Edmond, 2003; DeLoughrey, 2007). Despite the emphasis on their isolation, islands are also commonly seen as allegories or metonyms for the world. As Baldacchino (2007) wrote, they offer clairvoyance, acting as harbingers of things to come, but also as concentrated spaces in which the contours of modernity are put into relief (also Grove, 1996). In this way, islands provide an example of what Michel Foucault termed heterotopias, spaces that are "other": "as perfect, as meticulous, as well arranged as ours is messy, ill-constructed, and jumbled" (Foucault, 1986: 27). Islands thus represent an interesting paradox of modern thought because they are positioned as isolated spaces outside of the march of history, but simultaneously serve as a microcosm of modernity. It is in this sense that the Galápagos can be understood as an "evolutionary Eden": their role in Darwin's "discovery" of evolution ${ }^{2}$ makes them the site of a scientific origin story and the place from which a nonreligious ethics of life could be derived.

The image of Edenic nature also reflects perceptions of islands as isolated spaces apart from modernity (Slater, 1996), fueling a "pristine" imaginary. Yet as Elizabeth DeLoughrey (2007) argues, perceptions of island isolation are not statements of fact that describe the obvious nature of islands, but are themselves myths that must be explained. She argues that viewing islands as remote and isolated is an overused trope that belies their centrality to world trade and the very production of the modernity from which they are commonly taken to be isolated. Indeed, studies of island histories have detailed their importance for theories of natural

2 That Darwin 'discovered' evolution in the Galápagos is a narrative now widely rejected by historians and biographers (see Browne, 2003). 
science - the Galápagos are only one, famous case - as well as the origins of environmentalism (Grove, 1996; Quammen, 1996). They have also demonstrated their role as a laboratory for early colonialism (Crosby, 1986). For DeLoughrey (2007), the centrality of islands to modernity is overshadowed by the popularity of travel narratives and other accounts that stressed their isolation through the retelling of long, difficult maritime journeys and described the foreignness of island natures to European explorers.

For the Galápagos, early travel narratives such as Berlanga's that spoke of the islands' remoteness and inhospitable nature are supplemented by scientific statements of the evolutionary value of insularity. The isolated insularity of the Galápagos, which lie $1,000 \mathrm{~km}$ off the coast of Ecuador in the Pacific Ocean and were scarcely populated until the 20th century, is what is said to have famously made them a "natural laboratory of evolution" for Darwin (Dawkins, 2007: 6). In this environment, Darwin (along with Alfred Wallace) was one of the first to fathom what is now commonly recognized among ecologists and evolutionary biologists: oceanic archipelagos are places in which evolutionary processes are more clearly visible because their insularity and lack of predators allows for extreme adaptation. This often leads to species dwarfism or gigantism: the most famous case of which might be the giant tortoises for which the Galápagos are so well known (Quammen, 1996). Insularity also allows for adaptive radiation, an evolutionary process in which species diverge as they are ecologically separated - the classic example being that of the many species of "Darwin's finches," distinguishable by the adaptation of their beaks and made famous through the work of Peter and Rosemary Grant (Weiner, 1994). As one scientist explained in a popular science book:

"[The archipelago's] isolation is key to understanding the arrival and evolution of plants and animals in the Galápagos...Isolation is also key to understanding the historical role of the Galápagos in evolutionary thinking...when Charles Darwin first visited the islands they were much less accessible and largely untrammeled. Evolutionary tracks could be found and followed, un-obscured by the myriad crisscrossings of busier placers, especially the havoc-wreaking traffic of human beings" (Steadman, 1988: 26).

And as Durham (2009) explained, the archipelago's isolation, demanding ecological conditions, and relative absence of competitor or predatory species allowed for unique evolutionary adaptations which make species vulnerable to change. It is in this sense that the Galápagos can be understood as a "natural laboratory of evolution." As the metaphor suggests, their relatively isolated nature is what allowed for the evolution of such unusual endemic species.

Together, these scientific accounts and appeals to the cultural importance of islands thus serve to establish an understanding of the Galápagos as the site of a scientific origin story and its nature as pristine wilderness. In her account of island histories, DeLoughrey (2007) argues that, while the trope of isolation belies the centrality of islands to the construction of Western modernity, it simultaneously relegates indigenous populations to a primordial past. In the case of the Galápagos, the trope of Edenic nature serves to position nature as primordial while accounts of the islands as a natural laboratory suggest that they are sites of controllable isolation (Kohler, 2002). These tropes thus create an understanding of the Galápagos as a site of nature both spatially and temporally separate from society. But this understanding belies a 
significant part of the archipelago's material history. In the following section, we explore the material effects of these "pristine imaginations" by showing how they have worked to shape conservation goals as well as industry and development on the islands over the past 50 years.

\section{The Effects of 'Eden'}

Instead of being natural representations and universal truths, views of nature as wild or pristine are framings that reflect particular ways of seeing the world, and thus are political statements with particular effects (Cronon, 1996; Whatmore, 2002). As geographer Doreen Massey writes, the ways we conceptualize space and nature have profound material effects (Massey, 2005; also Hinchliffe, 2007). As discussed above, one of the effects of idealizations of a primordial, pristine nature in the Galápagos is to cast nature and culture as separate realms and to position people as always external to island space (Ospina, 2004). Rhetoric of the pristine nature of the Galápagos is presented as a universal truth, a scientific statement about the natural reality of the islands that does not leave any space for other histories. As Massey writes, the "cosmology of 'only one narrative' obliterates the multiplicities, the contemporaneous heterogeneities of space. It reduces simultaneous coexistence to place in the historical queue" (2005: 5).

This is why the idea of a crisis in paradise seems so paradoxical: according to the way we commonly imagine the Galápagos, there cannot, naturally, be a social presence there. Instead of nature and society existing contemporaneously, this rhetoric necessarily positions any coexistence as problematic. Thus this discourse has the dual effect of making past social histories in this space of "pristine nature" surprising and also of positioning current social presence as necessarily foreign. If Galápagos nature is primordial and isolated, then social presence there becomes associated with its opposite-modernity, a dystopian future that jeopardizes the sanctity of pure nature. This is the implicit understanding of nature that Dan Rather references in his newscast as he described the "battle being waged between Man and Nature" as the "human footprint is now threatening what took Nature eons to create" (Rather, 2008). In this account, the "human footprint" and associated landscape transformations are unnatural intrusions into primordial nature. Such representations of a "natural" antagonism between nature and society demonstrate the moral and political force of ideologies of pristine nature (Cronon, 1996; Ospina, 2004). What logically follows from Rather's description and others like it is an ethics of protection and isolation that shapes the field of politics and claims to natural resources in the Galápagos.

We argue that the discourse of pristine island Edens has had both direct and indirect material effects on the islands. First, it has directly shaped conservation work that seeks to restore landscapes to a previous "pristine" existence and has also influenced management policies that effectively bifurcate island spaces into discrete "social" and "natural" areas. Second, imaginations of pristine nature have shaped the major industry in the islands - tourism — and have also worked indirectly to structure patterns of investment in public infrastructure. By seeking to restore "pristine" nature in the Galápagos, these effects complete a materialconceptual feedback loop that naturalizes the pristine view of the Galápagos seen in nature documentaries. What's more, they are also political actions with particular effects. In what follows, we first explore approaches to conservation that seek to create a pristine Galápagos 
before turning to discuss how tourism and development were historically structured to highlight and complement this pristine vision.

Isolating the islands from human impact has long been a central conservation goal in the Galápagos. Historically, this was accomplished by policies that (a) physically bifurcated human-populated and protected park areas on the islands and (b) attempted to restore landscapes and ecosystems damaged through the effects of human presence. When the National Park was established, management plans followed the well-known "Yellowstone model" in which park territory was envisioned as being free of human presence. To this end, terrestrial areas not already inhabited were set aside for protection, thereby restricting existing communities to small enclaves within the Park; in total, $97 \%$ of the Galápagos was established as a protected park zone, while the remaining three percent was allotted for urban use and agricultural buffer zones.

This territorial division was complemented by conservation management plans that have largely been guided by a desire to restore and maintain the "natural state" of the archipelago (Grenier, 2007; GNPS, 2005). In 2002, scientists and conservationists working with the CDF published a Biodiversity Vision for Galápagos that outlined the goal of going "Back to Eden":

"[The] ultimate goal is the restoration of the populations and distributions of all extant native biodiversity and of natural ecological/evolutionary processes to the conditions prior to human settlement. If this extremely ambitious goal were one day to be achieved, it would represent the pinnacle of accomplishment in conservation biologythe restoration of the biological nature of the Galápagos Islands almost to the conditions of 1534" (CDF \& WWF, 2002: 48).

This quote reflects a scientific origin story to justify a vision of Galápagos as a natural museum where pristine nature should be restored and protected. Although Ospina notes that most conservationists realize such goals are not realistically attainable because "optimal conditions for management" cannot be reached (Ospina, 2006: 46), they clearly demonstrate a material application of understandings of island space as a place reserved for pristine nature, apart from social impacts.

Attempts to isolate and restore pristine nature complete a material-conceptual feedback loop that seeks to literally erase past material transformations of island landscapes. The Biodiversity Vision presents human influences as the primary threats to endemic biodiversity, principally (for terrestrial areas) because of habitat degradation, overexploitation, and interaction with alien species. Preventing future harm and restoring past damage caused by these concerns are top priorities for Park management. For example, one of the largest management initiatives to this end is a recently completed feral animal eradication program. Over the past 30 years, Park employees, working with the CDF and international experts, have eliminated or greatly reduced populations of pigs, donkeys, and goats from nine of the archipelago's 13 major islands. (Populations remain on four inhabited islands.) Over the last decade, "Project Isabela" employed both ground-based and aerial hunting methods, including more than 700 GPS-tagged "Judas goats," to kill more than 150,000 goats on Isabela and Santiago Islands. Invasive goat populations were seen as particularly harmful because their heavy grazing converted forest to grasslands and because they ate vegetation recuperating tortoise populations relied on. This US\$8.5 million project is an example of the conservation 
effort aimed to restore the "natural" health of island ecosystems to a state in which humaninduced invasive species and the habitat destruction they caused are no longer visible. As a published report on the program explains its motivation:

"The arrival of man in Galápagos provoked the beginning of the progressive deterioration of the natural environment of the islands, particularly because of the deliberate introduction of species of plants and animals for subsistence farming in these 'inhospitable' islands. The surroundings which these species found on their arrival was such that they could colonize in an accelerated manner, escaping man's control and becoming from then on, one of the worst threats to the island ecosystems" (Lavoie et. al., 2007: 6).

To demonstrate success, the 60-page Project Atlas (Lavoie et. al., 2007) gives numerous statistics about cost-effectiveness and also includes "Before and After" landscape photographs on the two islands that depict once barren landscapes recovering with grasses and small trees.

Project Isabela is thus one example of conservation management that seeks to erase the material impacts of past human presence in a space that should be "pristine" nature. Such projects, while important for the health of island ecosystems, complete a feedback loop by attempting to recreate imaginations of a pristine Galápagos that ostensibly existed before humans brought goats or other foreign creatures and otherwise disturbed the landscape.

In addition to its material impacts in restoring landscapes, conservation based on the "pristine" myth has another considerable effect in the Galápagos: causing conflict between different social groups on the islands. Geographers have long argued that through their material effects, goals to recreate pristine nature become deeply political issues. As Steven Hinchliffe (2007: 11) explained:

"Cronon and other environmental historians...clearly [said] that so-called wildernesses are peopled, have histories and geographies, and so are in some way or another are social as well as natural productions... To think otherwise, and thereby to act otherwise, is to potentially do great damage to those people and landscapes, plants and animals that they have helped to make (and that have helped to make them)."

In the Galápagos, conservation goals that idealize pristine nature, and which often largely ignore, if not overwrite, people's claims to life on the islands, have engendered a long history of conflict between local residents, scientists and conservationists. These conflicts are often framed as dichotomous battles between conservation and development, but ethnographic work has shown that they are much more complicated. ${ }^{3}$ Nevertheless, in our interviews, residents frequently expressed criticisms of the amount of money and effort dedicated to conservation and care for particular species of animals compared to the difficulties they face in caring for their families and creating what they consider a decent life. In the case of Project Isabela, residents complained of the waste of food resources associated with goat eradication (carcasses were largely left in situ, although populations maintained as livestock were not targeted) and local hunters (many of whom were employed for ground-hunting) felt their labor

\footnotetext{
${ }^{3}$ Several authors detail the nuances of these histories of conflict, e.g. Ospina (2004, 2006); Grenier (2007) and Quiroga (2009).
} 
should have been more extensively used. These responses to Project Isabela are just one example of the political effects of conservation policies that prioritize the restoration of a natural ideal over the concerns of residents. In the following section, we explore some of the material bases over which such conflicts arise (Ospina, 2004) and the ways in which they-as much as conservation goals - are shaped around imaginations of pristine nature. We begin by exploring how the islands' major industry (tourism) turns on the commodification of a pristine landscape, and the resulting social and economic inequalities. We then turn to infrastructure development, discussing how efforts to develop tourism lead to infrastructure investment patterns that also often eclipse the needs of local residents.

\section{The Tourism Industry}

From its inception, the rationale for establishing a National Park in the Galápagos was not only closely tied to its appeal for scientific research purposes, but also to the potential for economic development based on resource extraction and a possible tourism industry. For Huxley a national park in the Galápagos would serve as a means for understanding "the cosmic project of evolution" for eco-tourists and scientists alike. This goal reflected his near-religious commitment to evolution and desire to preserve "all sources of pure wonder and delight" so that "individuals could attain greater fulfillment" (Larson, 2001: 181). Where Western naturalists like Huxley had conceived of a national park in the Galápagos dedicated to scientific research (Grenier, 2007), the Ecuadorian government instead prioritized the islands as a site for resource extraction and other forms of development to reinforce the state's claim to sovereignty in the archipelago (Ospina, 2006). Capitalizing on these economic interests, the naturalists persuaded the Ecuadorian government to convert the majority of the archipelago into a national park by convincing them that the islands could become a tourist attraction, but only if the wildlife were protected (Grenier, 2007).

Six years after the creation of the national park, the Ecuadorian government consulted with naturalists (including some from CDF) and international marketing firms to examine the potential for developing tourism in the islands (Larson, 2001; Grenier, 2007). Early tour operators recognized that wildlife viewing constituted the main reason tourists would travel to the Galápagos, and advertising and promotion programs were developed to draw potential travelers to the islands (Larson, 2001). At the same time, popular books, articles, and nature documentaries were produced that focused on the islands' wildlife and natural landscapes, which worked to not only draw the interest of potential tourists but were also seen by many conservationists as beneficial for the cause of nature protection (ibid.).

By commodifying the archipelago's famous nature, contemporary travel narratives and propaganda build on and reinforce notions of the islands as isolated, primitive spaces. As Ospina (2006) notes, images of pristine nature in the Galápagos are produced through tourism propaganda that abstracts nature - most often charismatic megafauna such as giant tortoises or other unusual species - and presents it apart from its social and ecological contexts (Prudham, 2009). Numerous websites, travel brochures, and guidebooks highlight the natural history and physical setting of the islands while tantalizing potential tourists with the promise of adventure activities that will bring them in close contact with endemic flora and fauna. Popular essays, magazines and documentaries also serve to reinforce the idealized Galápagos that ultimately 
puts pressure on the tourism industry and conservationists alike to provide such experiences (Quiroga, 2009).

The representations of pristine nature that are commodified through such depictions are then replicated in the experience most tourists have in the Galápagos Islands. The model of tourism in Galápagos has resulted in what Diego Quiroga has termed an "ecotourism bubble"4 in which the social relations that make these natural experiences possible are hidden from the view of visitors (Quiroga, 2009). Since the inception of tourism in the Galápagos, the visitor experience has been carefully constructed to present an edited version of the islands that is 'natural', 'pristine', and relatively free of humans. As detailed in a report developed for one of the first touring companies in devising a plan of operations in the Galápagos:

"Except for the Darwin Station exhibits in Puerto Ayora, the cruises should steer clear of other humans and let the passengers commune with nature among themselves." (Little, quoted in Larson, 2001: 226).

The number of visitors to the Galápagos has grown tremendously since the 1970 s, when only a few thousand visited each year. In 2010, more than 170,000 people visited the archipelago (GNPS, 2011). Despite its increasing popularity, tourists continue to be attracted to Galápagos by the desire to see the unique wildlife in a natural setting, and to somehow walk in the footsteps of Darwin ${ }^{5}$ (Quiroga et al., 2009; Basantes, 2009). More than thirty flights bring tourists to the Galápagos each week and most board small yachts shortly after arrival. From these floating hotels, small groups of visitors visit various sites within the Galápagos National Park (GNP) and the Galápagos Marine Reserve (GMR) to participate in activities from hiking and wildlife-viewing to snorkeling and kayaking. Visitor itineraries are carefully regulated by the Galápagos National Park Service, and sites within the two protected areas can only be visited with a certified tour guide. Most tourists do not spend time in the small towns located on the four inhabited islands, and when they do it is often only for a brief period of time at the end of a boat-based tour, just prior to heading home. For the most part, local population growth is hidden from tourists (Quiroga, 2009), as is the waste that locals and visitors generate, the multitude of goods that arrive by cargo ship each week, and the infrastructure that is required to support tourists.

The lived experience for Galápagos residents is quite different from the "pristine" imagination of the islands and lies outside of the "ecotourism bubble." Many residents don't have the opportunity to experience some of the most unique and 'natural' places for which the archipelago is best known. Locals are subject to the same rules as foreign tourists who wish to visit the protected areas of the GNP and GMR, such that they must be on a set itinerary, can only visit sites selected and approved by the Park Service, and must be accompanied by a certified and trained guide. The expense of such tourism activities puts these places out of reach for many Galapagueños, and creates a situation in which they are living in a worldrenowned haven of tourism that for them is essentially off limits. And, despite the fact that a

\footnotetext{
${ }^{4}$ This concept is based on the idea of a "tourism bubble" in which the social relations or 'real' experiences of a performance, in this case tourism, are hidden from the view of the consumer (here, tourists). See Cohen (1988; 2002) and MacCannell (1973).

${ }^{5}$ Quiroga et al. (2009) report that over $87 \%$ of tourists in Galápagos ranked wildlife as very important or important to their decision to visit the islands.
} 
large proportion of the local population works in tourism or in service-based industries that support tourism, they do not benefit equally from their participation in this sector (Grenier, 2007).

The economic benefits of tourism in the Galápagos Islands are unequally distributed at the international, national and local levels. Of the US $\$ 419$ million dollars spent by tourists in Galápagos during 2007, only US\$62.9 million dollars entered the local economy (Epler et al., 2008). Many tourists book their trips through large travel agencies or tour companies based on the Ecuadorian mainland (or in some cases, internationally), who can promote the type of nature-based tourism and ecotourism their international clients are looking for (Quiroga, 2009). These large companies aren't necessarily aligned with small and medium-sized operators based in the Galápagos, and in such cases the local economy does not receive the full economic benefit of such tourism (Epler, 2007). The situation for the Galápagos economy is changing somewhat as local operators expand their share of the market and promote landbased tourism activities using the discourse of 'pristine' nature and conservation that has been used successfully by larger companies (Quiroga, 2009). However, there remains a concentration of tourism infrastructure in the hands of a few individuals and families who own many of the 80 tour vessels operating in Galápagos waters (Epler \& Proaño, 2008) as a result of the tourism permitting system that reinforces which groups can gain access to visitor sites in the GNP and GMR, and therefore influences the local distribution of wealth (Epler, 2007). The inequality in the tourism sector has led to conflict and tension among locals, a lack of trust in the permit system, and a sense that the process is not fair (Quiroga et al., 2009).

\section{Infrastructure Development}

Structural inequalities within the tourism industry that are based in part on conceptualizations of Galápagos as a pristine site have carried over into such other aspects of social life in the islands as infrastructure development, and as a result, public health. Expansion of the tourism industry to more than 170,000 visitors annually (GNPS, 2011) and growth of the local population to more than 19,000 residents (INEC, 2007) has outpaced basic infrastructure development in the Galápagos, particularly for water, wastewater, and sanitation services, to the point that the systems that do exist cannot adequately process waste or provide clean water. Not all infrastructure and basic services have been neglected however, as significant investments have been made to develop transportation and communication infrastructure that cater to tourists as the land-based tourism sector grows (Epler, 2007). For example, in the last few years, improvements have been made to expand the road network as the number of personal vehicles and taxis in the Galápagos increases; to improve the two main airports that accept commercial flights from the mainland; to increase the number of cargo ships that transport goods into the archipelago; and to develop telecommunication services such as highspeed internet and free wireless internet access. While these improvements do benefit the local population to varying degrees, it is ultimately the tourists and the tourism industry that seem to have gained the most from such projects.

Such inequalities in infrastructure development can be explained, in part, by historic efforts to limit the development and apportioning of public services, and more recently, a lack of resources to address the problem. In the period following establishment of the National Park, 
conservation was generally conducted without consideration for the local population (Epler, 2007; Gonzalez et al., 2008), and in some cases, counter to the best interest of the local communities (Gonzalez et al., 2008). According to Epler (2007), over the last thirty years management in the Galápagos focused on regulating activities within the protected areas of the archipelago, while "little attention was directed toward what was happening in the areas dedicated to colonization. The towns were bucolic communities, with little infrastructure or public services" (Epler, 2007: 40-41). In fact, in the past there were several proposals to limit public services in Galápagos (Gonzalez et al., 2008) for fear that they would promote continued population growth. Indeed, in its analysis of the recent crisis, the CDF argued that demand for pubic services is part of a vicious cycle of growth in Galápagos, and that as jobs and services are provided, they create a higher standard of living that is more attractive to potential migrants (Watkins \& Cruz, 2007), demonstrating continued skepticism of local development among some conservationists. The local population has continued to grow nonetheless, and public service deficiencies have only worsened. While the lack of infrastructure development today is less about willful denial of services, the problem has become more difficult to address because of past unwillingness to take appropriate action. This is coupled with a lack of financing for such projects at the municipal government level (Watkins \& Cruz, 2007), bureaucracy (e.g., the need for environmental impact assessments before carrying out water treatment and sanitation projects), and claims of corruption (Diario Hoy, 2007).

In a 2007 interview, one local conservationist complained that the majority of money that enters the Galápagos economy is directed at conservation, stating, "[It] is useless if it doesn't go to support administration and municipal services. Less environmental impact would occur as a result of better infrastructure." Indeed, in our interviews and other studies, local residents have argued repeatedly that policies focused solely on protected areas serve to engender conflict (Hennessy, 2010; also Ospina, 2006; Quiroga, 2009). Grenier (2007: 256) describes the sentiment among locals in Galápagos that conservationists care more about the well-being of animals than people, and that they "... combat any measure aimed at improving the living conditions of the islanders under the pretext that this would accelerate migration to the archipelago" (authors' translation). Local residents are well aware of the inequalities in the amount of resources that are allocated to support tourism and conservation, while public services for Galapagueños remain unimproved. A recent survey of Galápagos residents conducted by Quiroga \& Ospina (2009) demonstrates that health and sanitation ranked second (to migration) in a list of themes that they believe scientists should study in the islands. These findings are similar to those of an earlier study in which health and potable water were listed as the principal deficiencies in public services (Grenier, 2007).

It has long been recognized that access to clean water and a system to effectively manage waste is a necessity for residents (and tourists) in the Galápagos Islands, but these areas seem to have been particularly ignored. Freshwater is scarce in Galápagos, and the limited amount of water available for human use is frequently contaminated by salt water due to over-pumping (Buckalew et al., 1998), and by pollution from human waste due to the proximity of waste disposal areas to water sources, coastal areas, and the lack of wastewater treatment facilities (Kerr et al., 2004; Walsh et al., 2010). Despite recent discussions of developing regional water strategies and management plans for the archipelago, attempts to create clean drinking water systems, and political promises of improved facilities, the water and sewer situation remains a 
threat to the health of local people and the environment (Walsh et al., 2010). As a result, acute diarrheal diseases remain one of the most common causes of illness in the Galápagos Islands (MSP, 2007). In our interviews, families have reported a variety of poor health outcomes resulting from contact with contaminated water, including fungal infections and intestinal parasites (Walsh et al., 2010).

Not only does the water and wastewater issue affect the health of the residents of Galápagos and tourists alike, but it also negatively impacts the environment and compromises the 'pristine' idealization on which the islands are built (Grenier, 2007). Coastal pollution exists near the developed ports (Kerr et al., 2004; d'Ozouville, 2008), and poses a real threat to people and marine species, as the result of organic waste generated by households, businesses, and tourism boats (Kerr et al., 2004). Over-extraction of water has also become a serious problem with population and tourism growth, which threatens coastal lagoons and wetlands (Gelin \& Gravez, 2002), and has led to increased salinity of agricultural lands.

\section{Discussion}

In these ways, then, idealizations of pristine nature in the Galápagos have the double effect of spotlighting the remote archipelago as a unique place of significant natural and scientific importance, which has led to a booming tourism industry, and also leading to social conflict and uneven distribution of wealth and services that endanger the archipelago's prized nature. The question is, as the New York Times put it, "Can Darwin's lab survive success?" (Conlin, 2008). Although the rhetoric of crisis has surrounded Galápagos for decades, this question has become a major concern since the UNESCO and Ecuadorian declarations in 2007. The irony of the crisis declarations is that resulting media coverage often includes calls for people to visit the islands "before it's too late," which serves to increase social and environmental pressure. Although the Galápagos Islands were officially removed from the World Heritage 'In Danger' list in July 2010 by the World Heritage Committee, questions remain about the future of the archipelago. The de-listing, which came contrary to recommendations issued by the International Union for the Conservation of Nature (IUCN) and UNESCO, appears to reflect faith in the progress the Ecuadorian government has made in addressing issues rather than evidence of material improvements (IUCN, 2010). Indeed, despite official removal from the list, the rhetoric of crisis is likely to continue as people remain concerned about these material effects of the archipelago's fame and popularity with both tourists and a growing resident population.

In response to growing development and conflicts over the past 10 years, local residents and policy makers have called for increasing participation of local stakeholders in decision making. Since the crisis declarations, a number of publications by the National Park, the CDF, and affiliated scholars have sought to "re-imagine the Galápagos as a complex socioecological system" (Gonzalez et al., 2008: 1), or to take a "human ecosystem approach" (Watkins, 2008: 5) to management frameworks, instead of seeking to separate people and the environment. For example, in a 2009 book published by the National Park (Tapia et al., 2009: 15), the authors argue that: 


\section{E. Hennessy \& A. L. McCleary}

"[t]o analyze the current situation of the archipelago and be able to design innovative management models that will reverse current trends and solve the present crisis, it is imperative to understand and look at Galápagos differently. The local population must be considered part of this complex socio-ecological system, a system whose primary processes (primary production, water cycle, nutrient cycles, current systems, etc.) must be maintained if Galápagos biodiversity is to be conserved and social welfare enhanced".

Over the past 5 years, Park management plans in particular have begun to implement participatory governance structures (GNPS, 2005). One example of integrated management is the co-management regime for the Galápagos Marine Reserve that includes representatives of the National Park, local fisheries, and the tourism sector. Yet, despite some considerable successes, attempts at participatory management remain controversial because of perceived inequalities and pre-negotiated policy decisions, particularly in regard to opening yearly fisheries (Heylings \& Bravo, 2007).

In addition, despite their progressive goals, many of the attempts to re-envision the Galápagos as a "socio-natural system" retain a fundamental separation between nature and society (Hennessy, 2010). For example, calls to study the "human footprint" in the islands implicitly imply that human presence is unnatural and harmful. Although conservation frameworks that attempt to join nature and society have led to positive changes in the last few years, they continue to re-inscribe problematic dichotomies and open only a proscribed space for cultural and political differences. While the crisis declarations have led to some critical reflection on the material effects of success and the need for wider participation in decision-making, the ways that nature is imagined in the Galápagos have remained largely unquestioned. Yet, as we have shown, nature cannot be taken for granted. In the following section, we conclude by arguing that a re-thinking of the nature of the Galápagos is essential not only for understanding the complexity of social-environmental relations in the islands, but also for attempts to resolve this crisis moment.

\section{Conclusion}

In this paper, we have interrogated the conception of pristine nature which we argue undergirds the discourse of a recent crisis in the Galápagos Islands and its material effects. Drawing on environmental histories and geographies of the "production of nature," we argued that nature is not a natural realm separate from society, but is thoroughly social in the ways it is both materially shaped through histories of human interaction and endowed with particular meanings. We thus showed that idealizations of pristine, Darwinian nature in the Galápagos are not natural, nor historically accurate, but are a particular social production that became hegemonic with the founding of a national park in the mid- $20^{\text {th }}$ century. This production, we argued, has been particularly powerful because it frames the Galápagos as the site of a scientific origin story, combining popular Western cultural beliefs about islands with a scientific rationale for the value of island insularity. We then explored some of the material effects of this narrative as it motivates conservation efforts that complete a feedback loop as they work to erase the material impacts of the islands' social histories, and also structures the 
tourism industry and investment in public infrastructure in ways that create social inequalities and have negative impacts on the environment.

Declarations of crisis in the islands have called attention to a host of problems that will need to be addressed in the Galápagos, from exploitation of resources, to political paternalism and corruption, to short-term economic planning, to historical tensions between conservation and development goals. We have argued that a re-imagination of nature is likewise essential for overcoming a persistent discourse of crisis in the archipelago. If nature is not a pristine, untouched realm, but a particular way of thinking about ecosystems, then we must think differently about the history and future of the islands. As Bruno Latour argued with an understanding of the interconnectedness of nature and society, "History is no longer simply the history of people, it becomes the history of natural things as well" (Latour, 1993: 82). A revisioning of the Galápagos could be thought of as the converse of this statement - the history of Galápagos must not be understood only as a natural history, but also as a social history. Or, more precisely, it must be thought in terms of the relationality of these histories, how they are both co-produced and co-effective and thus have together in their intertwining shaped the space of the Galápagos.

Such a re-imagination of nature as always closely tied to society likewise requires a new, more open politics that does not start from, nor end, at an idealization of pristine nature. For nearly 50 years, idealizations of Darwinian nature, of protecting a pristine island environment, have structured political debate in the Galápagos by providing a pre-determined end goal. Today, we argue that for the Galápagos to move forward necessitates a politics of nature that is both open-ended and inclusive of people's place in the islands. As Massey (2005: 11) argues, drawing on Laclau:

"[O]nly if we conceive of the future as open can we seriously accept or engage in any genuine notion of politics. Only if the future is open is there any ground for a politics which can make a difference".

In the Galápagos, a politics that envisions the future as a return to 1534 is the epitome of a closed politics. There is no space here, whether for people or for political debate. For a politics that could make a difference to the health of nature (including people), the stranglehold that imaginations of pristine nature have on the islands would need to be removed. We contend that this involves a fundamental rethinking of the nature of nature and islands that authors such as Cronon, Hinchliffe, and Massey steer us toward. This new understanding would recognize that nature is always closely intertwined with societies, and that that is not necessarily a bad thing.

This re-imagination of nature in the Galápagos simultaneously suggests a re-imagination of islands and island space. Islands have long been thought of as remote, isolated places that are spatially and temporally separated from modernity, though this, as DeLoughrey (2007) suggests, is not the case any more than the idea that nature is separate from society. In the Galápagos, this myth of island isolation and idealizations of 'pristine' nature are mutually reinforcing. But, as we have explored, an imaginary that holds island nature as distinct from society necessarily positions connections with mainlands and the rest of the world as intrusions or invasions. Such understandings both deny dense histories of material flows and interconnections and work to frame contemporary globalization as a new, modern problem without precedent that jeopardizes the sanctity of islands. In the Galápagos, understandings of 
pristine nature work to frame the crisis as a battle between "Man and Nature" and to obscure the more specific problems at issue. If islands are to serve as allegories for the world, then we argue they should not be taken as representing anachronistic spaces outside of, threatened by, modernity, but should be thought to speak to the inseparability of nature and society, even in the most far-flung of places. This re-imagination, we argue, is key to beginning to effectively address the issues that jeopardize the health of island natures and populations.

\section{Acknowledgements}

This research was made possible by grants from the Social Science Research Council/Andrew Mellon Foundation, the Institute for Study of the Americas at the University of North Carolina at Chapel Hill, and the Carolina Population Center at the University of North Carolina at Chapel Hill. We would also like to thank two anonymous reviewers for their comments and those in the Galápagos who have participated in our research.

\section{References}

Baldacchino, G. (2007) 'Islands as Novelty Sites', The Geographical Review, Vol. 97, No. 2, pp. 165-174.

Basantes, J.F. (2009) Planning for Sustainable Ecotourism in the Galápagos Islands: Exploring Galápagos Tourists' Profiles and their Integration into Community-Based Tourism, Master's Thesis, University of Florida.

Bowman, R.I. (1960) Report on a Biological Reconnaissance of the Galápagos Islands during 1957. Paris, United Nations Educational, Scientific and Cultural Organization.

Browne, J. (1995) Charles Darwin: Voyaging. Princeton NJ, Princeton University Press.

Buckalew, J.O., James, M., Scott, L. \& Reed, P. (1998) Water Resources Assessment of Ecuador. US Army Corp of Engineers, Mobile District and Topographic Engineering Center.

Castree, N. a. B. B. (2001) Social Nature: Theory, Practice and Politics, New York, Blackwell Publishing.

Charles Darwin Foundation (CDF) and World Wildlife Fund (WWF) (2002) A Biodiversity Vision for the Galápagos Islands, R. Bensted-Smith (ed.), Puerto Ayora, Galápagos, CDF.

Cohen, E. (1988) 'Authenticity and commoditization of tourism', Annals of Tourism Research, Vol. 15, No. 3, pp. 371-386.

Cohen, E. (2002) 'Authenticity, Equity and Sustainability in Tourism', Journal of Sustainable Tourism, Vol. 10, No. 4, pp. 267-276.

Conlin, J. (2008) 'Can Darwin's Lab Survive Success?', The New York Times, New York.

Cronon, W. (1996) 'The Trouble with Wilderness; or, Getting Back to the Wrong Nature' in W. Cronon (ed.) Uncommon Ground: Rethinking the Human Place in Nature, New York, W.W. Norton \& Company, pp. 69-90. 
Crosby, A. (1986) Ecological Imperialism: The Biological Expansion of Europe, 900-1900, Cambridge, Cambridge University Press.

Darwin, C. (n.d. [1845]) Voyage of the Beagle Round the World, New York, Tess Press.

Dawkins, R. (2007). 'Foreword' in P.D. Stewart (ed.) Galápagos: The Islands that Changed the World, New Haven CT, Yale University Press. pp.6-7.

DeLoughrey, E. (2007) Routes and Roots: Navigating Caribbean and Pacific Island Literatures, Honolulu HI, University of Hawaii Press.

Denevan, W. (1992) 'The Pristine Myth: The Landscape of the Americas in 1492', Annals of the Association of American Geographers, Vol. 82, No. 3, pp. 369-385.

d'Ozouville, N. (2008) 'Fresh water: the reality of a critical resource' in Galápagos Report 2006-2007, Puerto Ayora, Galápagos, Ecuador, CDF / GNP / INGALA, pp. 146-150.

Diario Hoy (2007) Investigan contrato de agua potable. 04 Oct. 2007, Quito.

Durham, W. (2009) What Darwin found convincing in Galápagos, presentation at the Galápagos Science Symposium, Puerto Ayora, Santa Cruz, Galápagos, Ecuador.

Edmond, R. \& Smith, V. (eds.) (2003) Islands in History and Representation, New York, Routledge.

Epler, B. (2007) Tourism, the Economy, Population Growth, and Conservation in Galápagos, Puerto Ayora, Galápagos, Charles Darwin Foundation.

Epler, B. \& Proaño, M.E. (2008) 'How many tourists can Galápagos accommodate?' in Galápagos Report 2006-2007, Puerto Ayora, Galápagos, CDF/GNP/INGALA, pp. 36-41.

Epler, B., Watkins, G. \& Cárdenas, S. (2008) 'Tourism and the Galápagos economy' in Galápagos Report 2006-2007, Puerto Ayora, Galápagos, Ecuador, CDF/GNP/INGALA, pp. 42-47.

Foucault, M. \& Miskowiec, J. (trans.) (1986) "Of Other Spaces." Diacritics, Vol. 16, No. 1, pp. 22-27.

Galápagos National Park Service (GNPS) (2005) Plan de Manejo Participativo, Santa Cruz, Galápagos, Galápagos National Park.

Galápagos National Park Service (GNPS) (2011) Informe de Ingreso de Turistas 2010. Puerto Ayora, Santa Cruz, Galápagos National Park.

Gelin, A. \& Gravez, V. (2002) Knowledge and Conservation of Galápagos Islands Coastal Lagoons (Ecuador). Galápagos, Ecuador, Basler Stiftung für Biologische Forschung, Charles Darwin Biological Station and Galápagos National Park.

González, M., Montes, C., Rodríguez, J., \& Tapia, W. (2008) 'Rethinking the Galápagos Islands as a Complex Social-Ecological System', Ecology and Society, Vol. 13, No. 2, Article 13, www.ecologyandsociety.org/vol13/iss2/art13/. 
Grenier, C. (2007) Conservación contra natura: las islas Galápagos, IFEA / Emvajada de Francia en Ecuador / IRD / Universidad Andina Simón Bolívar / Ediciones Abya-Yala.

Grove, R. (1996) Green Imperialism: Colonial Expansion, Tropical Island Edens and the Origins of Environmentalism, 1600-1860, Cambridge, Cambridge University Press.

Harrison, P. (1947) Galápagos Islands: A Brief Study of Their Occupation, Evacuation and Present Occupation by United States Military Forces. Historical Office. October 28, 1947.

Hennessy, E. (2010) Crisis in Nature's Eden: Conserving Nature and Culture in the Galápagos Islands. Master's Thesis, University of North Carolina at Chapel Hill (UMI No. 1478157).

Heylings, P. \& Bravo, M. (2007) 'Evaluating Governance: A process for understanding how co-management is functioning, and why, in the Galápagos Marine Reserve', Ocean \& Coastal Management, Vol. 50, No. 3-4, pp. 174-208.

Hinchliffe, S. (2007) Geographies of Nature, London, SAGE.

Huxley, J. (1966) 'Charles Darwin: Galápagos and After' Chapter 1 in R.I. Bowman (ed.) The Galápagos. Proceedings of the Galápagos International Scientific Project, Brussels, Charles Darwin Foundation, Palais des Academies, pp. 3-9.

Instituto Nacional de Estadisticas y Censos (INEC) (2007) Censo de Población y Vivienda, Galápagos 2006, Quito, INEC.

International Union for the Conservation of Nature (IUCN) (2010) 'Galápagos off danger list but still at risk', IUCN Press Release, 29 July, www.iucn.org/knowledge/news/?5763/Galapagos-off-danger-list-but-still-at-risk

Kerr, S., Cardenas, S. \& Hendy, J. (2004) Migration and the Environment in the Galápagos, Wellington, New Zealand, Motu Economic and Public Policy Research.

Kohler, R. (2002) Landscapes and Labscapes: Exploring the Lab-field Border in Biology, Chicago IL, University of Chicago Press.

Larson, E.J. (2001) Evolution's Workshop: God and Science on the Galápagos Islands, New York, Basic Books.

Latour, B. (1993) We have never been Modern, Cambridge MA, Harvard University Press.

Latour, B. (2004) Politics of Nature: How to bring the Sciences into Democracy, Cambridge MA, Harvard University Press.

Lavoie, C., Cruz, F., Carrion, G. V., Campbell, K., Donlan, C. J., Harcourt, S. \& Moya, M. (2007) The Thematic Atlas of Project Isabela: An illustrative document describing, step-bystep, the biggest successful goat eradication project on the Galápagos Islands, 1998-2006. Puerto Ayora, Galápagos: Charles Darwin Foundation. 60pp.

Massey, D. (2005) For Space, London, Sage. 
MacCannell, D. (1973) 'Staged Authenticity: Arrangements of Social Space in Tourist Settings', American Journal of Sociology, Vol. 79, No. 3, pp. 589-603.

Ministerio Salud Publica (MSP) (2007) Diez principales causas de morbilidad según provincias - Ecuador 2007, www.msp.gov.ec/index.php?option=com content\&task=blogsection\&id=21\&Itemid=175

Ospina, P. (2006) Galápagos, naturaleza y sociedad: actores sociales y conflictos ambientales, Quito, Corporación Editora Nacional.

Ospina, P. (2004) 'El Hada del Agua. Ética Ambiental y Actores Sociales en Galápagos.' Journal of Intercultural Studies. Extra Series 30. Osaka, Japan.

Prudham, S. (2009) 'Commodification' in N. Castree, D. Demeritt, D. Liverman and Bruce Rhoads (eds.) A Companion to Environmental Geography, Oxford, Blackwell Publishing pp.123-142.

Quammen, D. (1996) The Song of the Dodo: Island Biogeography in an Age of Extinctions, New York, Scribner.

Quiroga, D. (2009) 'Crafting nature: the Galápagos and the making and unmaking of a "natural laboratory”, Journal of Political Ecology, Vol. 16, No. 1, pp. 123-140.

Quiroga, D. \& Ospina, P (2009) 'Percepciones sociales sobre la ciencia y los científicos en Galápagos' in W. Tapia, P. Ospina, D. Quiroga, J.A. González and C. Montes (eds.) Ciencia para la sostenibilidad en Galápagos: el papel de la investigación científica y tecnológica en el pasado, presente y futuro del archipiélago, Quito, Parque Nacional Galápagos, Universidad Andina Simón Bolívar, Universidad Autónoma de Madrid and Universidad San Francisco de Quito, pp. 109-126.

Quiroga, D., Mena C., Suzuki, H., Guevara, A. \& Pozo, P. (2009) Socioeconomic Effects of Climate Change in the Galapagos Islands: an emphasis on people, unpublished report, Quito Ecuador, Universidad San Francisco de Quito.

Rather, D. (2008) Dan Rather Reports: Pollution in Paradise, Episode 340, December 9. HDNet.

Raffles, H. (2002) In Amazonia, Princeton NJ, Princeton University Press.

Salwen, P. (1989) Galapagos: The Lost Paradise, New York, Mallard Press.

Slater, C. (1996) 'Amazonia as Edenic Narrative' in W. Cronon (ed.) Uncommon Ground: Rethinking the Human Place in Nature, New York, W.W. Norton \& Company. p. 114-131.

Sluyter, A. (1999) 'The Making of the Myth in Postcolonial Development: MaterialConceptual Landscape Transformation in Sixteenth-Century Veracruz', Annals of the Association of American Geographers, Vol. 89, No. 3, pp. 377-401.

Soper, K. (1995) What is Nature? Culture, Politics and the Non-human, Oxford, Blackwell. 
Steadman, D. a. S. Z. (1988) Galápagos: Discovery on Darwin's Islands, Washington DC, Smithsonian Institution Press.

Stewart, P. D. (2007) Galápagos: The Islands that Changed the World, New Haven CT, Yale University Press.

Tapia, W., Ospina, P., Quiroga, D., González, J.A., Montes, C. (2009) Ciencia para la sostenibilidad en Galápagos, Galápagos, Parque Nacional Galápagos.

Townsend, C. (1925) "The Galápagos Tortoises in Relation to the Whaling Industry: A Study of Old Log Books.” Zoologica, Vol. 4, No. 3, pp. 55-135.

Walsh, S.J., McCleary, A.L., Heumann, B.W., Brewington, L., Raczkowski, E.J. \& Mena, C.F. (2010) 'Community Expansion and Infrastructure Development: Implications for Human Health and Environmental Quality in the Galápagos Islands of Ecuador', Journal of Latin American Geography, Vol. 9, No. 3, pp. 137-159.

Watkins, G. a. C., F (2007) Galápagos at Risk: A Socioeconomic Analysis of the Situation in the Archipelago, Puerto Ayora, Galápagos, Ecuador, Charles Darwin Foundation.

Watkins, G. (2008) A Paradigm Shift in Galápagos Research, Galápagos Islands, Ecuador, Charles Darwin Foundation.

Weiner, J. (1994) The Beak of the Finch: A Story of Evolution in Our Time, New York, Vintage Books.

Whatmore, S. (2002) Hybrid Geographies: Natures, Cultures, Spaces, London, Sage.

Worster, D. (1994) Nature's Economy: A History of Ecological Ideas, Cambridge, Cambridge University Press. 